\title{
ТЕХНОГЕННЫЕ ЧАСТИЦЫ В СОВРЕМЕННЫХ АНТРОПОГЕННЫХ ОТЛОЖЕНИЯХ НА УРБАНИЗИРОВАННОЙ ТЕРРИТОРИИ (НА ПРИМЕРЕ Г. ЕКАТЕРИНБУРГА)
}

\author{
Селезнев А.А. ${ }^{1}$, Ярмошенко И.В. ${ }^{1}$, Малиновский Г.П. ${ }^{1}$, Илгашева Е.О. ${ }^{1}$, Киселева Д.В. ${ }^{2}$ \\ ${ }^{1}$ Институт промьииленной экологии УрО РАН, Екатеринбург, sandrian@rambler.ru \\ ${ }^{2}$ Институт геологии и геохимии им. академика А.Н. Заварицкого УрО РАН, Екатеринбург
}

Современные антропогенные отложения на урбанизированных территориях являются относительно мало изученным компонентом. Верхняя часть геологического разреза городских территорий, искусственно созданные городские ландшафты, отдельные их компоненты претерпевают постоянную трансформацию [1]. Образующийся на поверхностях рыхлый осадок, продукт процессов современного седиментогенеза, - самостоятельная фация, являющаяся одним из основных геохимическим барьеров урбанизированной среды. Использование современных антропогенных отложений как геоиндикаторного компонента позволяет получать информацию о состоянии окружающей среды городской территории $[2,3]$. Изучение состава и свойств современных антропогенных отложений является значимым для понимания механизмов геохимической трансформации окружающей среды города. Морфология и химический состав частиц отложений позволяют:

- выявить корреляции между элементным составом отложений и техногенных частиц,

- определять источники микроэлементов в компонентах окружающей среды,

- выявлять процессы, приводящие к накоплению поллютантов,

- определять механизмы переноса и накопления тяжелых металлов в современных отложенияx $[4,5]$.

В настоящей работе изучалась морфология и химический состав, также проводилась классификация обнаруженных в современных антропогенных отложениях техногенных частиц. Исследование проводилось на примере г. Екатеринбурга. В качестве объекта исследования выбрана поверхностная фация отложений - отложения в локальных понижениях микрорельефа (иначе говоря, осадок или грязь из луж) на территориях жилых кварталов. Отбирались пробы компонентов окружающей среды, участвующих в формировании отложений. В разных географических частях города в пределах улично-дорожной сети, на разных зонах литогенного субстрата выбрано шесть экспериментальных площадок - типичных микроландшафтов (кварталов с многоэтажной застройкой). На площадках проводился отбор проб:

- снега на ненарушенных участках снежного покрова, снегогрязевой смеси (пульпы) и наледи на тротуарах, обочинах и дорогах, парковках, из куч и навалов, на внутридворовых проездах, детских площадках, газонах в зимний период;

- почв и грунтов, отложений локальных понижений микрорельефа на газонах, детских площадках, организованных и неорганизованных парковках, дорожной пыли летом.

После разделения проб компонентов окружающей среды на гранулометрические фракции из навесок 0.1-0.25 и 0.25-1 мм под бинокуляром МБС-10 с выделялись техногенные образования. Частицы фотографировались с помощью оптического микроскопа Axioplan 2 фирмы Carl Zeiss и бинокулярного микроскопа МБС-10, оснащенных фотоаппаратом Olypmus C-5060. Химический состав частиц и структура частиц определялись методом сканирующей электронной микроскопии (CЭM). Исследования проводились на сканирующем электронном микроскопе JSM-6390LV фирмы Japanese Electron Optics Laboratory с интегрированной системой энергодисперсионного анализа (ЭДС) INCA Energy 350 X-Max 50 фирмы Oxford INCAEnergy. На СЭМ исследовались поверхности объектов без предварительной подготовки. Для повышения контраста изображения напылялось углеродное покрытие. С одной частицы снималось 4-27 изображений поверхности в отраженных электронах в зависимости от однородности поверхности, числа включений и их визуального разнообразия: 2-16 изображений на основе частицы, до 19 изображений получали с инклюзий. Изображение поверхности, полученное СЭМ, включало процентное содержание элементов. Элементный состав основы и включений частиц определялся усреднением содержания элементов с полу- 
ченных изображений. Исследования проводились в ЦКП «Геоаналитик» на базе ИГГ им. академика А. Н. Заварицкого УрО РАН.

Всего было отобрано 60 проб компонентов окружающей среды на территориях кварталов. Было получено 32 техногенных частицы. Проанализированные техногенные частицы могут быть отнесены к 13 различным типам:

- четыре вида шлаков (гранулированные, камневидные, стекловидные и шлаки металлургического производства),

- микросферы (сферулы) (силикатные, силикатно-железистые, железные),

- фольга,

- стекло битое,

- стружка нержавеющей стали,

- обломки строительных материалов (кирпич, штукатурка),

- частицы шин.

Гранулированные шлаки представляют угловатые полупрозрачные образования черного или темно-коричневого цвета, размер частиц 0.5-1мм. Камневидные шлаки представляют полупрозрачные окатанные образования, серого, темно-коричневого, темно-зеленого цвета размером 0.5-0.8 мм. Частицы стекловидного шлака имеют размер 0.5-1 мм и выглядят как частицы желтоватого, коричневого цвета с характерным для стекла раковистым изломом. Частицы металлургического шлака непрозрачные, угловатые, неокатанные, черного цвета, размер 0.4-1 мм.

Частицы сферической формы разного цвета и структуры рассеяны в материале отобранных компонентов окружающей среды. Силикатные микросферы самые крупные, имеют размеры от 0.5-1 мм. Размер силикатно-железистых микросфер 0.45-0.75 мм. Структура силикатных и силикатно-железистых микросфер корродированна, на их поверхности видны каверны, углубления и трещины. Так же присутствуют гладкие микросферы. Микросферы не являются идеальными шариками, чаще сплюснуты или имеют неправильную форму. Железистые сферулы отличаются правильной шарообразной формой и небольшими размерами (3-80 мкм). Они, в отличие от силикатных и силикатно-железистых, имеют полигональную структуру.

Обломки строительных материалов образуют два типа частиц: обломки кирпичей и штукатурки. Первые характеризуются хорошей степенью окатанности и красно-коричневым цветом. Раз-
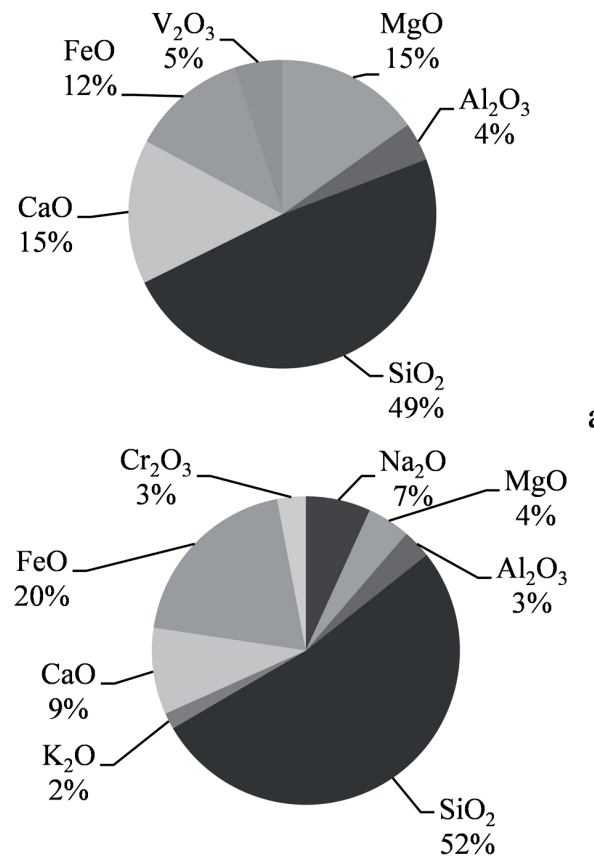

a
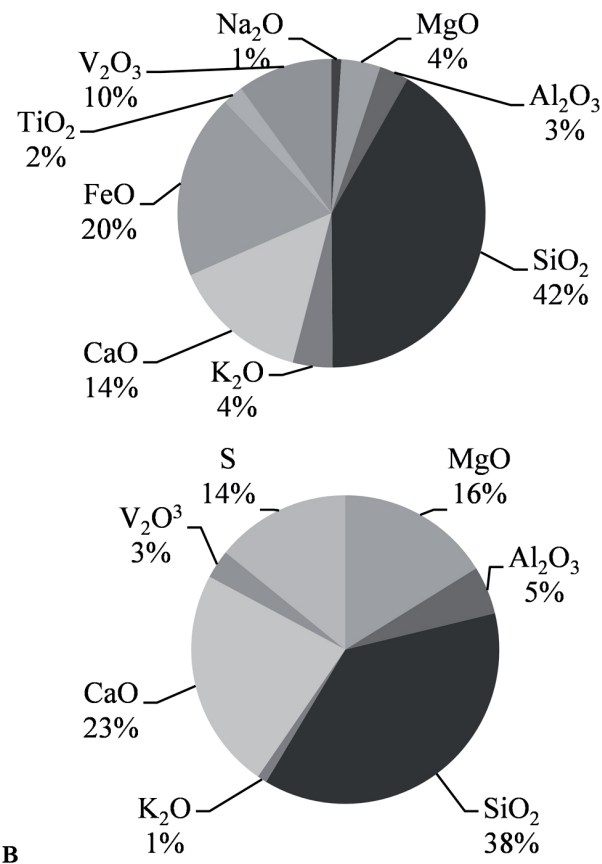

6

$\Gamma$

Рис. 1. Усредненный состав частиц шлаков, полученный с помощью ЭДС. a - гранулированные шлаки, б - камневидные шлаки, в - стекловидные шлаки, г - металлургические шлаки. 

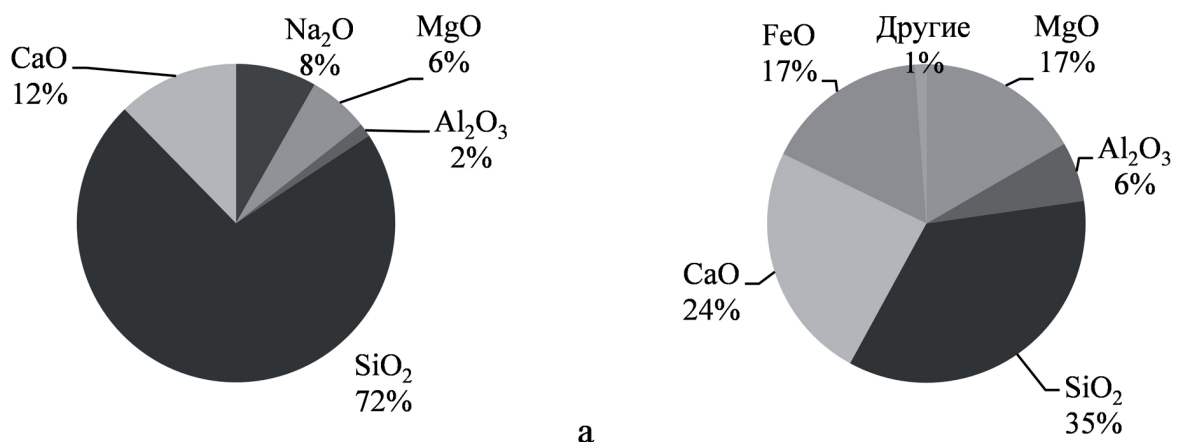

a

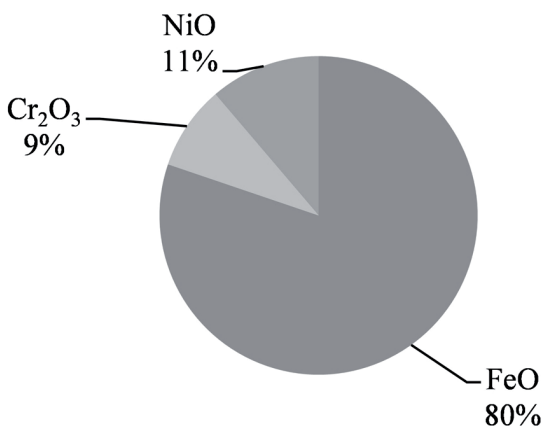

$80 \%$

Рис. 2. Усредненный состав сферических частиц, полученный с помощью ЭДС.

а и б - силикатные микросферы, в - железистые.

мер составляет 500-700 мкм. Частицы штукатурки тонкие, уплощенные, характеризуются высокой хрупкостью, от светло-серого до белого цвета. Размер частиц редко превышает 800 мкм. При съемке на оптическом микроскопе имеют изотропную структуру.

Частицы автомобильных шин чаще всего удлиненные, с гладкой поверхностью, непрозрачные, матовые. Цвет таких частиц черный, размер от 200 до 800 мкм.

Усредненный состав частиц шлаков, полученный с помощью ЭДС, представлен на рис. 1. Усредненный состав сферических частиц представлен на рис. 2.

В исследованных компонентах окружающей среды в г. Екатеринбурге техногенные частицы составляют до $30 \%$ от объема твердого материала в зимний период и до 25 \% в летний. В зимний период наибольшие выпадения частиц шлака наблюдаются в центральной, северной и восточной частях города, наименьшие - в южной и юго-западной.

Техногенные частиц в современных антропогенных отложениях могут быть в дальнейшем использованы как маркер процессов современного седиментогенеза на урбанизированной территории для изучения потоков миграции и выявления депо техногенного вещества и поллютантов.

Исследование выполнено при финансовой поддержке РФФИ в рамках научного проекта № 16-35-60044 мол_а_дк.

\section{Литература}

1. Экология города (под ред. Н.С. Касимова). М. : Научный мир. 2004. 624 с.

2. Селезнев А.А. Эколого-геохимическая оценка состояния урбанизированной среды на основе исследования отложений пониженных участков микрорельефа (на примере г. Екатеринбурга). [Текст]: дисс. канд. геол.-мин. наук: 25.00.36: защищена 26.03.2015: утв. 01.07.2015 / Селезнев Андриан Анатольевич. Екатеринбург, 2015. 141 с.

3. Селезнев А.А. Оценка возраста загрязнения грунтов на урбанизированных территориях с использованием датирования по содержанию цезия-137 / А.А. Селезнев, И.В. Ярмошенко, А.Н. Медведев // Геоэкология. Инженерная геология. Гидрогеология. Геокриология. 2014. № 4. С. 329-336.

4. Bourliva A. On the morphology, geochemical characteristics and magnetic properties of urban road dust particles from the historic center of the city of Thessaloniki, Greece / A. Bourliva, N. Kantiranis, L. Papadopoulou, E. Aidona, C. Christoforidis, and P. Kollias // Proceedings of the 12th International Conference on Environmental Science and Technology. Rhodes, Greece. 2011. A-238 - A-245.

5. Gieré R. Lumpkin. Micro- and nanochemistry of fly ash from a coal-fired power plant / R. Gieré, L. E. Carleton, and G. R. Lumpkin // American Mineralogist. 2003. V. 88. P. 1853-1865. 